DOI:http://dx.doi.org/10.18524/1810-4215.2019.32.181911

\title{
MATERIAL OF COMETARY NUCLEI AND ASTEROIDS CAN BE STUDIED IN THE EARTH'S ORBIT
}

\author{
A. P. Vidmachenko, A. F. Steklov \\ Main astronomical observatory of the NAS of Ukraine \\ Kyiv, Ukraine,vida@mao.kiev.ua, stec36@i.ua
}

\begin{abstract}
The Solar system is formed from a primary gas-dust cloud. Asteroids and cometary nuclei are made of the same substance. Therefore, the study of their debris will help determine their properties. It is best to investigate the substance of meteoroids in the laboratory. The presence of radioactive chemical elements in meteorites provides important information about their age. The study of the isotopic composition and content of uranium and thorium gives an age of a meteorite substance of $\square 4.6$ billion years. Measurement of cosmogenic isotopes in meteorites and analysis of their content allows us to determine the size, mass and age of meteoritic bodies before falling to Earth. By measuring the content of tritium and helium in a meteorite, the average intensity of the cosmic rays bombarding the sample is estimated. Every day, 1001000 tons of meteorite material falls on the Earth's surface. A large mass falls to the surface under the action of meteor showers. Meteor showers are formed from the remnants of the nuclei of known comets and asteroid bodies. To study the substance of the nucleus of comet Churyumov-Gerasimenko, a spacecraft was sent to it worth about 1 billion euros. We offer, that to study the material of some nuclei of comets and asteroids, it is possible to take meteoroid samples directly in outer space in the Earth's orbit. There, meteoroid particles must be captured, preserved and delivered to Earth for a thorough study. To capture matter from a specific parent cometary nucleus or asteroid in outer space, traps made of silicon dioxide, which are filled with airgel, can be used. The material of the traps allows you to capture particles flying at high speed without overheating them. This allows you to save organic and other molecules in such particles. Such traps should be activated at the moments of maximums of the selected meteor showers.
\end{abstract}

Keywords: meteor, meteor shower, gas-dust cloud, isotope composition, capture of matter.

АНОТАЦИ. Сонячна система сформована з первинної газопилової хмари. 3 такої ж речовини складаються астероїди і кометні ядра. Тому вивчення їх уламків допоможе визначити їх внутрішні властивості. Найкраще речовину метеороїдів досліджувати в лабораторних умовах. Наявність радіоактивних хімічних елементів в метеоритній речовині дає важливу інформацію про їх вік. Вивчення ізотопного складу і вмісту урану і торію дає вік метеоритної речовини $\approx 4,6$ млрд. років. Вимірювання космогенних ізотопів в метеоритах та аналіз їх вмісту дозволяе визначити розміри, масу та вік метеоритних тіл до падіння на Землю. За зміною вмісту тритію та гелію в метеориті оцінюють середню інтенсивність бомбардуючих зразок кос- мічних променів. Щодня на поверхню Землі падає 1001000 тонн метеоритної речовини. Більша маса потрапляє на поверхню у час дії метеорних потоків. Метеорні потоки утворюються із залишків ядер відомих комет і астероїдних тіл. Для дослідження речовини ядра комети Чурюмова-Герасименко, до неї був направлений космічний апарат вартістю близько 1 млрд. євро. Ми пропонуємо, що для вивчення матеріалу деяких ядер комет та астероїдів, можна відбирати зразки метеороїдів прямо в космічному просторі на орбіті Землі. Там метеороїдні частинки необхідно піймати, законсервувати і доставити на Землю для ретельного дослідження. Для захоплення речовини з конкретного батьківського кометного ядра або астероїда, в космічному просторі можна використовувати виготовлені з діоксиду кремнію пастки, які заповнені аерогелем. Матеріал пасток дозволяє захопити частинки, що летять 3 великою швидкістю, не перегріваючи їх. Це дозволяє зберігати в таких частинках органічні та інші молекули. Подібні пастки повинні бути задіяні в моменти близькі до максимумів обраних метеорних потоків.

Ключові слова: метеороїд, метеорні потоки, газопилова хмара, ізотопний склад, захоплення речовини

The Solar system was formed from a primary gas-dust cloud. Asteroids and cometary nuclei consist of the same primary substance. In this regard, we can assume that the secret of the origin of our system can remain inside asteroids and cometary nuclei.

Therefore, the study of their fragments will help answer many of the questions posed. The invasion of these meteoroids into the Earth's atmosphere leads to their interaction with air molecules.

The degree of this interaction and its consequences depend on the value of the extra-atmospheric speed of the meteoroid. Its boundary value is determined by the magnitude of the second cosmic velocity for our planet and for the solar system. The speed of the Earth in its orbit around the Sun is $\approx 30 \mathrm{~km} / \mathrm{s}$. And the maximum possible speed of meteoroids in the Earth's orbit is $\approx 42 \mathrm{~km} / \mathrm{s}$. Therefore, the speed of the oncoming meteoroid relative to the Earth will be equal to $\approx 72 \mathrm{~km} / \mathrm{s}$; and meteoroids that catch up with the Earth - a little more than $11 \mathrm{~km} / \mathrm{s}$. Under such conditions, the rate of meteoroid invasion of the atmosphere is in the range of $11.2-72 \mathrm{~km} / \mathrm{s}$. At such high speeds, the energy of a meteoroid with a mass of $\approx 7 \mathrm{~g}$ and a speed of $72 \mathrm{~km} / \mathrm{s}$ exceeds $20 \mathrm{MJ}$.

With such energy values, a body entering the Earth's atmosphere transfers a huge impulse to air molecules. Each collision heats a portion of the front of its surface and slows down its movement. With a deeper penetration 
of the body into the atmosphere, air density increases; the number of its interactions with atmospheric molecules is also growing. This leads to mechanical fragmentation of the meteorite into parts. Moreover, more fragile bodies begin to fragment at a high height, and more durable ones at a much lower level.

It is best to determine the structure, mass, density and chemical composition of a meteoroid in a laboratory study of its substance. But for now, we can only remotely observe meteors, or obtain information when registering the interaction of meteoroid dust particles with special sensors installed on spacecraft.

The presence of radioactive chemical elements in meteorites provides important information about their age. It is determined using the decay laws of natural radioactive isotopes. For example, some isotopes of uranium and thorium, having half-lives from 700 million to 14 billion years, decay, forming lead isotopes. Therefore, the study of the modern isotopic composition of lead and the relative contents of uranium and thorium gives the age of a meteorite substance equal to 4.6 billion years. Cosmogenic isotopes also play an important role in determining the time intervals from the moment of fall, i.e., the age of terrestrial meteorites.

Measurements of some cosmogenic isotopes have also shown that meteorites are tens and hundreds of thousands of years old. An analysis of their content allows us to determine the initial size and mass of meteorite bodies before falling to Earth.

So, under the influence of cosmic rays in meteorites, a radioactive helium isotope is formed - tritium. Therefore, according to changes of the tritium and helium content in the meteorite with depth, the average intensity of the cosmic rays, which bombarded the sample, is estimated. And the initial "pre-atmospheric" form, volume and mass of the meteorite body are also may estimated by the content of the helium isotope. In terms of chemical composition, meteorites practically do not differ from terrestrial rocks. But in meteorites, which have been found on Earth surface, rare or generally unknown minerals. Sometimes tiny grains of diamond come across, apparently, arising as a result of some kind of impact.

Until now, it was possible to study the composition of those cometary nuclei and asteroids whose meteorite materials fell to the Earth's surface (Churyumov et al. 2016). Every day, 100-1000 tons of meteorites falls here (Churyumov et al. 2014; 2015; Vid'Machenko 1995; Vidmachenko 2009; Vidmachenko et al. 1979; Vidmachenko \& Morozhenko 2014; Vidmachenko \& Steklov 2013).

And most of their mass appeared on the surface during the action of meteor showers. They arise when the Earth, during its orbital motion, passes through long clusters of meteoric matter in orbit around the Sun. This is repeated annually, and their active action lasts from several days to months (Dashkiev et al., 2018).

Most of these flows are formed from the remnants of the nuclei of known comets, and for several - from asteroid bodies (Dashkiev et al. 2017, Vidmachenko \& Vidmachenko 2007). For example, the parent body of meteor shower Quadrantides - is asteroid $2003 \mathrm{EH}$; Virginides 2003 BD44, 2002 FC and 1998 SJ70; Geminides - 3200 Phaeton; Arietides - 1566 Icarus. For the meteor shower Lirides is considered as source Comet C / 1861, for etaAquarids and Orionides - are Halley's comet; alphaCapricornids - 169P / NEAT, Delta-Aquarids - 96 / Machgolts, Perseides - Swift-Tuttle 1862III, Draconides 1900III Jacobini-Zinner, Taurids - Enke, Leonids Tempel-Tutl, Ursids - 8P / Tuttle.
Therefore, samples of the nuclei of the above comets and some asteroids can be taken in near space.

Recall that to study the substance of the nucleus of comet Churyumov-Gerasimenko, an apparatus was sent to it, worth about 1 billion euros. NASA after 2021 is planned to catch a small asteroid using an unmanned probe; then it will be delivered to the orbit of the Moon, and, after the selection of the necessary samples, they will be sent to Earth for a detailed study. But we offer that in order to study the material of some cometary nuclei or asteroids, it is not necessary to "catch" an entire object at great distances. To do this, we can take meteoroid samples of some selected comets or asteroids from the above list, right in outer space in Earth's orbit. It is here that meteoroid particles can be captured, mothballed and delivered to Earth for research using high-quality equipment (Vidmachenko \& Steklov 2018).

Devices for capturing matter in outer space can be traps filled with an airgel made of silicon dioxide. These were used in the study of the substance of the comet 81P / Wild by the probe "Stardust" (Rietmeijer, 2016). The material of the traps allows you to capture particles flying at high speed without overheating them.

This allows you to save both organic and other molecules in such particles (Gorlenko et al., 2000; Kozyrovska\&Vidmachenko, 2018; Vidmachenko\&Steklov, 2017). We propose equipping orbital comic systems with such cells, which should be used at the moments of the maximums of the selected meteor showers. Micrometeorites captured by such cells in space and delivered to Earth will not be affected by high temperature. Therefore, they can be delivered here for thorough research. Ensuring the sterility of the meteoroid substance will provide valuable information that may relate to possible extraterrestrial life during astrobiological studies.

And wherein, to study samples of the nuclei of comets and asteroids, it is not necessary to send special probes for millions of kilometers. To implement such a program, it is necessary to capture matter from the parent cometary nucleus or asteroid during the action of a particular meteor shower.

\section{References}

Churyumov K.I., Steklov A.F., Vidmachenko A.P. et al: 2015, ASR, 11(2), 99.

Churyumov K.I., Steklov A.F., Vidmachenko A.P. et al.: 2016, Meteoroids 2016, ESTEC, Noordwijk, 63.

Churyumov K.I., Steklov A.F., Vidmachenko A.P. et al.: 2014, Some results of regular observations of the twilight bolides (FOP "Kostiyk N.P.”Vinnytsia.) 98.

Dashkiev G.N., Steklov A.F., Vidmachenko A.P.: 2017, 48LPSC, Texas LPI Co. 1964, id.1135.

Dashkiev G.N., Vidmachenko A.P., Steklov A.F. et al.: 2018, 49LPSC, Texas LPI Co. 2083, id.1107.

Gorlenko V.M., Zhmur S.I., Duda V.I. et al.: 2000, OLEB, 30, 6, 567.

Kozyrovska N.O., Vidmachenko A.P.: 2018, 20 ISC AS $Y S$, Uman, 86.

Rietmeijer F.J.M.: 2016, Meteoritics \& PS, 51(3), 574.

Vid'Machenko A.P.: 1995, KPCB, 1(4), 14.

Vidmachenko A.P.: 2009, ASR, 6(1), 56.

Vidmachenko A.P., Klimenko V.M., Morozhenko A.V.: 1979, AAfiz, 39, 84.

Vidmachenko A.P., Morozhenko O.V.: 2014, The phys. Char. of surface Earth-like planets. (MAO, NULESU, Kyiv), 388.

Vidmachenko A.P., Steklov A.F.: 2013, ASR, 9(2), 146.

Vidmachenko A.P., Steklov A.F.: 2017, 19 ISC AS YS, Ukraine, 21.

Vidmachenko A.P. Steklov A.F.: 2018, ASR, 14(1), 15.

Vidmachenko A.P., Vidmachenko H.A.: 2007, AstAlm, 53, 195. 